УДК 61:377.4:378.147.88

\title{
ПІДВИЩЕННЯ ЯКОСТІ НАВЧАННЯ ПРАКТИЧНИМ НАВИЧКАМ У ПІСЛЯДИПЛОМНІЙ МЕДИЧНІЙ ОСВІТІ 3 ВИКОРИСТАННЯМ МУЛЯЖІВ ТА ТРЕНІНГОВИХ КЛАСІВ
}

\author{
О. М. Хвисюк, В. Г. Марченко, В. В. Жеребкін, О. В. Грищенко, І. А. Жадан, \\ К. І. Бодня, О. І. Сергієнко, І. А. Соболєва \\ Харківська медична академія післядипломної освіти
}

\section{PERFECTION OF PRACTICAL SKILLS WITH USING OF FANTOM IN POST-GRADUATE EDUCATION PROCESS}

\author{
O. M. Khvysiuk, V. H. Marchenko, V. V. Zherebkin, O. V. Hryshchenko, I. A. Zhadan, \\ K. I. Bodnya, O. I. Serhiyenko, I. A. Sobolieva \\ Kharkiv Medical Academy of Post-Graduate Education
}

\begin{abstract}
У статті розглянуто проблему недостатньої практичної підготовки лікарів на етапі післядипломної освіти. Для підвищення якості навчання рекомендовано застосування тренінгів на фантомах, що дозволяє відпрацювати деякі практичні навички безпечно для паціснтів, моделювати і контролювати різні мануальні дії, які потребують невідкладної медичної допомоги.
\end{abstract}

In the article the problem of insufficient practical training in post-graduate medical education process is given. In order to provide high quality of medical care in clinics, an advance trainings with using of fantom, which permit to work some practical skills safe for patients, to model and control different manual action, which need emergence medical care.

Вступ. Особливість сучасного розвитку медичної науки полягає у постійній та динамічній зміні певних уявлень та технологічних підходів. Лікарі, що працюють у закладах охорони здоров'я, часто відчувають брак знань щодо сутності та застосування нових технологій у наданні допомоги хворим у тій чи іншій сфері медицини. Вміння та знання, якими людина під час навчання оволодіває, $€$ динамічним процесом, що ніколи не зупиняється. Лікар-фахівець не має права вважати, що у своїй справі він знає і може усе. Якщо трапляється така ситуація, то зупиняється позитивний розвиток лікаря і відбувається втрата його якості як спеціаліста. 3 урахуванням цього в Україні була прийнята Концепція безперервної освіти. Вона полягає в необхідності стимулювання у лікарів розуміння необхідності постійного фахового зростання. Сучасний темп розвитку клінічних, лабораторних знань, удосконалення діагностичних засобів та лікувальнодіагностичної апаратури веде до того, що для надання допомоги хворому на сучасному рівні фахівець повинен відповідати сучасним вимогам медичної науки, а саме - мати певний рівень знань та практичних навичок. Прикладом цього може бути Національний проект “Нове життя”, згідно з яким в УК- раїні організується мережа перинатальних центрів. Це вимагає від лікарів удосконалення та відпрацювання окремих навичок, які необхідні для надання висококваліфікованої спеціалізованої медичної допомоги (відповідної до лікувального закладу ІІІ рівня).

Основна частина. Вирішальним фактором, який може позитивно вплинути на якість знань лікаря під час проходження циклів як ТУ, так і ПАЦ, є інтерактивне навчання; це навчання в процесі оволодіння практикою. При такому підході отримання знань, а особливо навичок, проходить через осмислення власних вмінь та дій. Коли ту або іншу маніпуляцію медичний працівник доводить до рівня автоматизму, то часто навіть сам не замислюється над тим, як він це виконує. У той же час, при проведенні аналізу своїх дій, людина може оцінити власні можливості та відчути брак тих чи інших знань та навичок. Крім того, під час навчання слухачі мають унікальну можливість ознайомитися та проаналізувати досвід інших фахівців з різним рівнем підготовки та світосприйняттям, отримати додаткову інформацію, навчитися аналізу та моделювання ситуації, прийняття спільних рішень у пошуках шляхів її вирішення. Впровадження інтерактивних методик в педагогічний процес дає

() О. М. Хвисюк, В. Г. Марченко, В. В. Жеребкін та ін. 
змогу задіяти не тільки розум лікарів, що навчаються, а й спонукати їх до творчого підходу при вирішенні фахових завдань.

З урахуванням вищесказаного, особливістю післядипломного навчання лікарів $є$ досить високі вимоги до викладачів. Так, викладання фахових знань повинно проводитися тільки тими спеціалістами, які самі $€$ фахівцями високого класу та можуть проводити заняття на достатньо високому професійному рівні; які спираються на останні розробки у своїй галузі, здатні використовувати усі сучасні дидактичні прийоми.

Навчання дорослої людини має певні особливості. Найкращі результати досягаються тоді, коли слухачі мають достатню мотивацію і навчаються за власним бажанням, розуміють значення засвоєння теми заняття саме для себе. У тих випадках, якщо сподівання слухачів щодо отримання знань або засвоєння навичок через якісь причини не здійснюється, якість навчання $є$ гіршою. Як вказує педагогічна практика, найкраща якість передачі знань у дорослій аудиторії спостерігається за умови активного залучення слухачів до процесу навчання. Особливістю фахової аудиторії є наявність певного досвіду, яким вони можуть ділитися та допомагати один одному.

Умови навчання можна значно покращити за допомогою викладача. На думку Девіда Колба (1984 р.), якщо людина хоче досягти ефективних результатів у навчанні, то для цього необхідно володіти чотирма вміннями:

1) реальним досвідом;

2) результативним (рефлективним) спостереженням;

3) абстрактним формуванням понять (абстрактна концептуалізація);

4) схильність до активного експериментування.

За ствердженням Д. Колба, для повноцінного процесу навчання у навчальному курсі необхідне комплексне використання конкретного досвіду, спостережень, теорії, практичного застосування. Концентрація тільки на одному, “улюбленому” стилі навчання може загрожувати так званим “паралічем навчання”. Крім того, за словами Кенні і Рейда, “надзвичайно важливо для викладача розуміти, що сам він віддає перевагу своєму власному, даному йому від природи, стилю навчання і що у виборі технік він має враховувати цілі навчання, а також переваги та стилі навчання його учасників".

Процес навчання найкраще перебігає при активному залученні всіх учасників практичного заняття до засвоєння практичних навичок шляхом їх відпрацювання із застосуванням анатомічних муляжів. Так, у
Харківській медичній академії післядипломної освіти для професійно орієнтованого навчання широко залучаються анатомічні муляжі. Тренінгові класи та центри організовані та застосовуються при викладанні анестезіології (кафедра дитячої анестезіології та інтенсивної терапіі), реанімації новонароджених (кафедра неонатологіi), надання допомоги при невідкладних станах (кафедра медицини невідкладних станів, медицини катастроф), акушерства та гінекології (кафедра перинатології, акушерства та гінекологіi). При цьому використовуються муляжі окремих ділянок тіла людини, що дає змогу відпрацювання практичних навичок щодо надання допомоги у тих випадках, коли це важко реалізувати в клінічних умовах, а саме через болючість маніпуляцій або їх впливу на життєві функції. Прикладом такого є застосування гінекологічного муляжу (нижня частина торса - ділянки живота і таза - дорослої жінки в натуральну величину) для навчання клінічним навичкам: бімануального гінекологічного обстеження, що включає пальпацію матки; зондування порожнини матки; введення і видалення ВМК; анестезіологічний муляж дає змогу відпрацьовувати методику інтубації трахеї тощо. Для навчання лікарів-неонатологів та у викладанні надання невідкладної допомоги дорослим використовують муляжі, що повністю відповідають анатомічним особливостям живої людини і створюють умови відпрацювання реанімаційних дій лікарями відповідного профілю.

Застосування анатомічних муляжів при навчанні практичним навичкам лікарів має декілька переваг, а саме: у разі допущення помилки або неправильної дії слухачі та лікарі-інтерни не травмують пацієнтів, в будь-який момент можливо зупинити демонстрацію для пояснення або виправлення помилок; у виконанні навички одночасно можуть практикуватися кілька учасників, що скорочує тривалість занять; складні етапи можна неодноразово повторити на муляжі без проведення всієї операції; місце проведення практики не обмежується тільки клінікою чи операційною, а ії̈ час - годинами прийому пацієнтів; учасники можуть практикуватися в послідовному i правильному виконанні етапів маніпуляції у будь-який час і стільки разів, скільки необхідно для іiі засвоєння; проведення клінічної підготовки можливе в тих клініках, де потік пацієнтів обмежений. При застосуванні муляжів у процесі клінічної підготовки лікарів дуже важливо пам'ятати, що інструменти для проведення процедури та рекомендовані заходи з профілактики інфекцій повинні максимально відповідати реальній ситуаціі. 
Як уже було зазначено, для досягнення успіху учасникам слід працювати на муляжах у максимально наближених до реальних умовах і з використанням реальних інструментів. Мало того, необхідно неодноразово повторити процедуру з точним дотриманням iii етапам стандартних підходів. Практику на муляжі необхідно проводити доти, доки учасник не продемонструє володіння навичкою і певний ступінь професіоналізму у виконанні певної процедури. Тільки тоді йому буде дозволено перейти до роботи з пацієнтами.

Висновок. Таким чином, наш досвід підтверджує думку про необхідність подальшого поширення використання сучасних муляжів при проведенні практичних занять 3 лікарями на післядипломному етапі навчання. Це сприятиме покращенню якості оволодіння практичними навичками слухачами та підвищить рівень їх задоволеності навчальним курсом. 